\title{
野荣カルシウムの渻化吸收率について \\ On the Rate of Aborption of Calcium in Vegetables
}

\author{
国立栄養研究所 (National Institute of Nutrition) \\ 田村 盈之輔 (Einosuke Tamura) 高居百合子 (Yuriko Takai, ) \\ 早川 德 子(Tokuko Hayakawa) 森本 喜代(Kiyo Morimoto) \\ 鈴木 秀夫 (Hideo Suzuki)
}

From the nutritional standpoint of Japanese people, the deficiency of calaium in their food has been pointed out recently. As we Japanese take it generally from vegetable foods and small fishes, it is very important to imvestigate the utilization of calcium in vegetable fcods on human beings. However, we have not so many experiments "about absorption of calcium in vegetable foods on human beings, especially in leaf vegetables.

To determine the absorption rate of calcium in cabbage and "Tsukena", the following experiment of 3 cases was made. In one case, 4 experimental subjects were given the basal diet which contains polished rice as the main food stuff and side dishes which are kept constant as to the amount and the Rind. In other cases, same subjects were given 1, $100 \mathrm{~g}$ of cabbage or "Tsukena" per head per day added to the basal diet after boiling.

It was found that the absorption rate of calcium in cabbage and "Tsukena" is higher on every experimental subjects than we had supposed, and generally the former is better than the latter. The average absorption rate of calcium in cabbage and "Tsukena" is $48.6 \%$ and $34.8 \%$ respectively.

1. 緒言 日本人のカルシウム摄取量は昭和 25 年度国民栄養調査成績に於ても 1 人 1 日当 $n$ 平均 $0.37 \mathrm{~g} !=$ て, 資源調查会食糧部会に於て定められた基準量 $1.0 \mathrm{~g}$ に比して遥かに少い。これは, 食品分析表 (昭 25)に よる計算值てあるため, 著者等の行つた栄養掫取量の分析値と計算値の比較より考えても, 少な過ぎる感は あるが，それでも摄取基準量には及ばないことは推定される。これは日本人の食物が，極めて乳製品に乏し

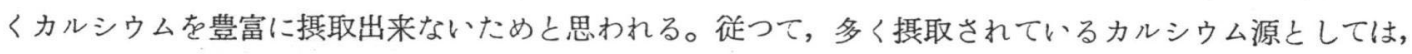
魚介類, 野菜類等で, 野菜のカルシウムは日本人のカルシウム源として相当利用されていることが想像され る。野菜カルシウムの人体利用については, Rose, Blatherwick \& Long, McLaughlin によよりよく利用さ れると報告されているが, 他方, ホーレン草並にその混合野菜については McClugage \& Merdel, Sherman \& Hawley, Edelstein 等, Schlutz 等も, カルシウムの利用が良好てないこと走報告している。これについ ては，ホーレン草中の後酸により利用が低下することを白鼠を用いて Finke \& Sherman が明らかにして いる。従つて, 苳酸の少ないキャべッの利用度はホーレン草よりはるかに良好であるのを認めている。しか し, このカルシウム利用の低下が, 鉴酸含量のみに影響されるかは, 向検討の余地があるであろう。著者等 は, 白鼠に於て牛乳カルシウムに匹敵するといわれるキャベッのカルシウム吸収率を人体に於て検し, 偷, 漬菜についてもそのカルシウムの吸収率を見て比較した。 


\section{2. 実験方法}

（1）被検者 健康成年男子 4 名

(2) 試験期間 昭和 26 年 8 月 31 日 第1表 提 取 食 品

$\sim 9$ 月 7 日

準 備 期 8 月 31 日 9 月 1 日 キャべッ期 9 月 2 日 9 月 3 日 基本食期 9 月 4 日 9 月 5 日 漬菜 期 9 月 6 日 2 月 7 日

(3) 供試食品

主として白米 1 人 1 日 $420 \mathrm{~g}$ t 3 回に撖取せしめた。準備期にには日常 食献立による副食を与え, 試験期に は第 1 表の如く, 野菜以外はカルシ ウム含量少いものを選んて与えた。 即ち, 基本食期には主食の他にカル

\begin{tabular}{|c|c|c|c|c|c|c|c|}
\hline 試験期 & 食品 & 朝食 & 昼食 & 夕食 & $\begin{array}{r}\mathrm{Ca}_{\frac{9}{9}} \\
\mathrm{~g}\end{array}$ & $\begin{array}{r}\mathrm{P} \text { 量 } \\
\mathrm{g}\end{array}$ & \begin{tabular}{|l} 
嘼白質 \\
\end{tabular} \\
\hline 基 & 白 米 & $140 \mathrm{~g}$ & $140 \mathrm{~g}$ & $140 \mathrm{~g}$ & 0.053 & 0.456 & 22.0 \\
\hline 本 & 牛肉(赤身) & 50 & 50 & 50 & 0.019 & 0.346 & 30.7 \\
\hline 食 & 油 & 10. & 10 & 14 & - & - & - \\
\hline 期 & 食塩(局方) & 3 & 5 & 5 & - & - & - \\
\hline 計 & 片 栗 粉 & & 3 & 5 & $\begin{array}{l}0.002 \\
0.531\end{array}$ & $\begin{array}{l}0.007 \\
0.809\end{array}$ & $\begin{array}{r}0.1 \\
52.8\end{array}$ \\
\hline $\begin{array}{c}\text { キャベッ期 } \\
\text { 計 }\end{array}$ & キャベッ & 300 & 300 & 500 & $\begin{array}{l}0.457 \\
0.531\end{array}$ & $\begin{array}{l}0.207 \\
1.016\end{array}$ & $\begin{array}{l}15.5 \\
68.3\end{array}$ \\
\hline $\begin{array}{c}\text { 漬 菜 期 } \\
\text { 計 }\end{array}$ & 菜 & 300 & 300 & 500 & \begin{tabular}{|l|}
1.243 \\
1.317
\end{tabular} & $\begin{array}{l}0.429 \\
1.238\end{array}$ & $\begin{array}{l}14.0 \\
66.8\end{array}$ \\
\hline
\end{tabular}

シウムの少い食品，キャべッ期，漬菜期に二於ては，それぞれ，基本食期献立の上に，キャべッ或は漬菜を朝 $300 \mathrm{~g}$, 昼 $300 \mathrm{~g}$, 夕 $500 \mathrm{~g}, 1$ 日計 $1100 \mathrm{~g}$ t油いためした後, 薏て摄取せしめた。又, 調理並!二领料には蒸 溜水を用、，ビタミン類の補給として 1 人 1 日パンビタン 1 鈽宛を投与した。油を用いていたかたのは，カ ルシウムの吸収が油により影響されないといわれるため，又，熱量補給と，㵶維を柔かくするためである。

(4) 試料の分析方法

食品並に䔬便中のカルシウムは AOAC法により，橉は Shinowara，Jones，Reinhart の方法によつた。 (5) 消化吸収率の算定方法

各試験期に於けナカルシウム並!二粼の消化吸収率は, 摄取食品中のカルシウム並に粹量に対して, 排泄䔬 便中のカルシウム並に辉量を不吸収分と見做して消化吸収率を算出したが, 野菜カルシウム吸収率は, 摄取 野菜カルシウム量に対して, 野菜試験期蕒便中のカルシウムより基本食期䔬便中カルシウムを差引いたもの を不吸収方と見做して，消化吸収率を算出した。

その他の消化吸収試験方法の詳細

第 2 表 基本食期に於计る $\mathrm{Ca}$ 摄取量並に排泄量

については從来栄養研究所に於て行 われて来た方法と同様のため省略す る。

\section{3. 实験方法}

第 $2 \sim 6$ 表に示寸如くである。

\begin{tabular}{|c|c|c|c|c|}
\hline 被検者 & 量 ${ }^{\text {日摄取Ca }}$ & 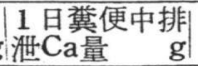 & $\begin{array}{l}1 \text { 日尿中排泄 } \\
\mathrm{Ca} \text { 量 }\end{array}$ & 出 \\
\hline M & 0.074 & 0.050 & 0.062 & -0.038 \\
\hline $\mathrm{S}$ & 0.074 & 0.095 & 0.046 & -0.067 \\
\hline $\mathrm{Y}$ & 0.074 & 0.079 & 0.045 & -0.050 \\
\hline $\mathrm{T}$ & 0. 074 & 0.093 & 0.073 & $\cdots 0.092$ \\
\hline
\end{tabular}

第3表 キャベッ期 $\mathrm{Ca}$ 吸収率

\begin{tabular}{|c|r|r|r|r|r|r|}
\hline 被 & 検 \\
\hline
\end{tabular}

( 30$)$ 
第 $5 \cdot 6$ 号

栄養学 雑誌

151

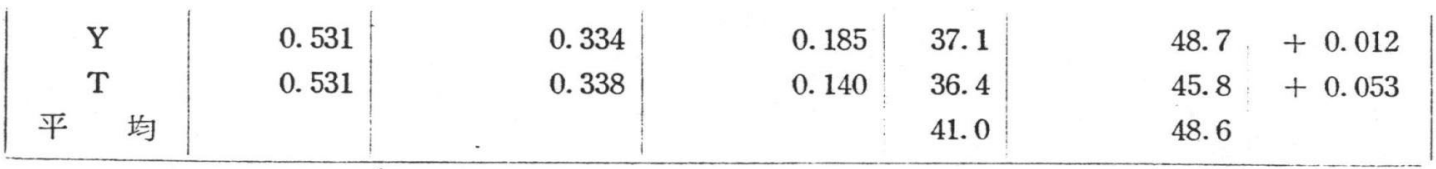

第 4 表 漬菜期 $\mathrm{Ca}$ 吸収率

\begin{tabular}{|c|r|r|r|r|r|r|r|r|}
\hline 被 & 検 \\
\hline
\end{tabular}

第 5 表 キャベッ期 $\mathrm{P}$ 吸収率

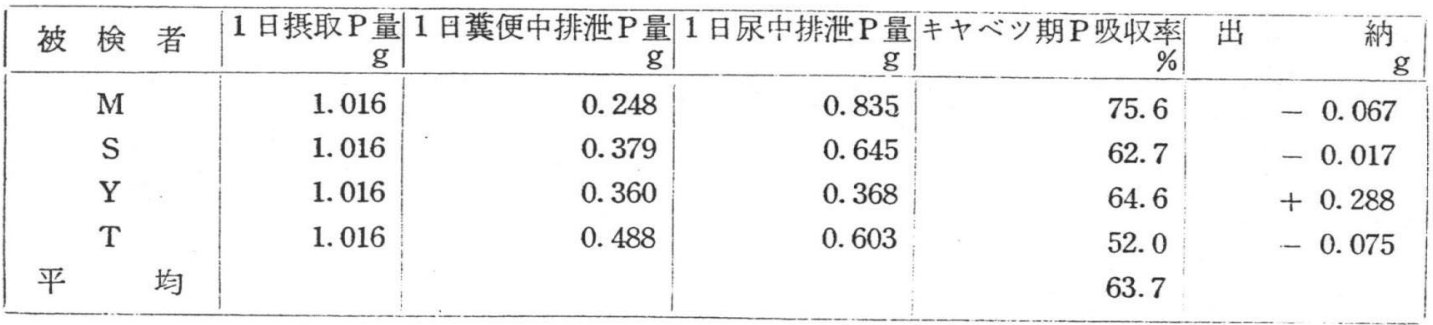

第 6 表 潰菜期 $\mathrm{P}$ 吸収率

\begin{tabular}{|c|c|c|c|c|c|c|c|}
\hline 被 & 検 & 者 & 1 日摂取 $\mathrm{P} \frac{\text { 量 }}{\mathrm{g}}$ & 1 日翼便中排泄 $\mathrm{P}$ 量 & $\mid \begin{array}{r}1 \text { 日尿中排泄 } \mathrm{P} \text { 量 } \\
\mathrm{g}\end{array}$ & $\begin{array}{r}\mid \text { キヤ ゙ッ期P吸収率 } \\
\%\end{array}$ & $\begin{array}{r}\text { 納 } \\
g\end{array}$ \\
\hline & $\mathrm{M}$ & & 1.238 & 0.463 & 0.584 & 62.6 & +0.195 \\
\hline & $\mathrm{S}$ & & 1. 238 & 0.403 & 0.189 & 67.0 & +0.646 \\
\hline & $\mathrm{Y}$ & & 1.238 & 0.445 & 0.400 & 64.1 & +0.393 \\
\hline & $\mathrm{T}$ & & 1.238 & 0.349 & 0.559 & 71.8 & +0.330 \\
\hline 平 & & 均 & & & & 66.4 & \\
\hline
\end{tabular}

\section{4. 総括}

健康成年男子 4 名について，キャベッ，漬菜のカルシウム消化吸収率を見たのにキャベッのカルシウム

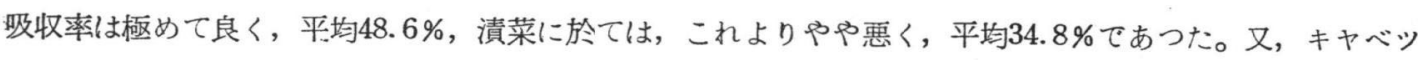
期並に漬菜期のカルシウム出納はいすれも正であつた。各野菜試験期に於!ナる䗲の吸収率を見たのにキャべ ツ期にては平均 $63.7 \%$ ，漬菜期にては $66.4 \%$ あつた。

本研究には一部文部省科学試験研究費の補助を受けた。厼, 被検者, 横井正雄, 清水照彥, 松本錬太郎氏 等の御協力を感謝し, 供試白米に関して食糧研究所谷達雄技官の御援助に深謝の意を表する。

\section{文献}

1）厚生省；国民栄着の現状 (昭和28年度成績).

2) 総理府資源調査会; 栄亘と食糧， 6, 243 (昭 29 ).

3) 田村, 西原, 磯部, 横田, 松野; 第 7 回栄養・食糧学校総会 (昭 28 ).

4) M.S. Rose ; J. Biol. Chem, 41,349 (1920).

5) N. R. Blatherwick, M. L. Long: J. Biol, Chem, 52, 125 (1922). 
6) L. McLanghlin : J. Biol. Chem. ,74, 455, (1927).

7) H. B. McClugage, L. B. Mendel : J. Biol. Chem. , 35, 353 (1918).

8) H. C. Sherman, E. Hawley : J. Biol. Chem., 53, 375 (1922).

9) E. Edelstein, H. Langetein : Deutch, Med. Woch., 57, 839 (1931).

10) F. W. Shultz, M. Morse, H. Oldham : Am. J. Dis. Chid. , 46, 757 (1933).

11) M. L. Finke, H. C. Sherman : J. Biol. Chem., 110, 421 (1935).

12) E.F.Kohman: J. Am. Diet. Assoc. , 10, 100 (1934).

13) M. G. Mallon, J. Jorodom, M. Johnson; J. Biol. Chem., 88, 163 (1930).

14) F. R. Steggerda, H. H. Mitshell ; J. Nutr., 45, 201 (1951).

15) 五島：栄養と食糧，7，180（昭 29 )

抄 錄

\section{世界の暻物}

Lord Boyd-Orr (F.A. Oのfirst director-general) 著“食物と末来”の要旨

白人のdilenma 一一食物之云jものは社会的安定 と経済的繁栄の基礎をなすものである, 即ち飢餓が 促来の多くの革命のもとであり，そして現在アジア で起つている暴動の根源も飢餓にある。この世から 飢餓が消失しなければ世界には決して平和は訪れな いであう。白人が，西欧文明を破壊し，悲惨な世 界戦争を結果吉る所の軍事的, 経済的優位性を世界 に於て維持するか，若しくは現在の優秀な工業生産 を利用して地球上の資源を発展させ，それによつて この世から飢と貧乏をなくするか，一後者の道を たどれば白人が 3 世紀に亘る征服によつてかち得た 世界支配力を䇸失することになる。か゚，この二者択 一は白人にとつてはむずかしい問題である。

世界の人口一世世界の人口は今世紀の終りまでは 現在の 24 億から40億まで増加するが，40〜60億を限 度としてそれ以後は減少するであろう。文化程度が 低くて, 現在急速に人口増加をしつつある国民は彼 等の生活と教育の程度が向上すれば西ヨーロッパの 諸国の如く，人口増加は次第に下向の傾向をたどり はじめる。これ!関連し，農業増産についても現在 の耕作地或は牧草のすへてに新しい改良された方法 が適用されたならば，世界の食物供給霄は倍加され るであろうし, 又もし現在行われている灌溉, 除草, 其他の方法によつて地球上の面積を増加するような
方法をとれば，地球は60億の人口を支えることが出 来るという農業技術専門家たちの評価は疑う余地は ないように思われる。又肥料の使用によつてなされ る各種改良, 植物疾病の調節, 生産高の多い品種の 使用，家畜類の種の選択と飼育法の改良なども大切 セある。

世界の食糧問題解決のための国際的試案——"保 健と農業の結合 " と云う概念を導き出す国際運合之 F.A.O.の仕事は重要である。

以上Lord Boys-Orr の論文の概要であるが，人 間の栄養要求量に関する知識についてのへててる部 分には一つの誤つた記述がある。

以前は激しい肉体労働は筋肉の損耗を補うために 余分の蛋白質を必要とすると思われていた，と説明 しておきながらこの著者は其の後の研究がこの仮説 を支持しなくなつたと云うことを述へていない。

これを要するに"第一次世界大戦後科学を抑圧し 人類社会をして新しい勢力に同調する機会を与え る॥ことは不可能てあると云う彼の説にある種の不 安を見出して残念に思うのたが，然し全世界の政治 家が一緒になつていいかにしたならば新しい科学の 世界に適応するような世界秩序を新しくつくり出す ことが出来るかを考えることが急務である゙と云う. 結論には賛意を表するものである。

From : Nature, Vol.172, No. 4374 August, 1953 一機部しつ子 抄訳— 